There is no feeling in Oregon that the people are going to usurp the business of the legislature, though the ballot this year does look like it. The legislature has all the work it can do and if it is so inclined can forestall legislation at the polls, except upon propositions like the single tax. Voting on such questions is the penalty of popular law-making, but the results are reassuring. There is no question of the continued interest of the people and the average public opinion seems to be at least as sensible as what Mr. F. N. Judson has called the deliberate representative judgment.

\title{
Personal and Bibliographical
}

\section{J. W. GARNER}

In order that, beginning with 1909 , the volume of the Review may correspond with the calendar year, no August, 1908, number was issued. The present number completes volume two.

The Fifth Annual Meeting of the American Political Science Association will be held in Washington, D. C., and Richmond, Va., December 28 to 31 . At the first session, to be held jointly with the American Historical Association, Monday evening, December 28, in Washington, the President of the Association, Mr. James Bryce, will deliver his address. The Tuesday morning session, also to be held in Washington, will be devoted to papers dealing with questions of international law. In the afternoon a special train will take members of the two associations to Richmond, where sessions will be held until Thursday afternoon, the general topics being recent State constitutions, municipal government, the increase of federal power and influence, the problems of colonial government as revealed by ten years' experience in Porto Rico and the Philippines, and the teaching of political science.

The recent death of Prof. Felix Stoerk in his fifty-seventh year was a distinct loss to the science of international law and politics. Dr. Stoerk was born in Austria and received his doctorate from the University of Vienna. From 1878 to the time of his death he was a prolific contributor to the literature of political science and international law. It was to the Revue de droit international et de législation comparée and the Journal de droit international privé that most of his contributions were made, though he occasionally published articles in other periodicals. In 
1879 he published a work entitled Option und Plebiszit bei Eroberungen und Gebietszessionen which increased his reputation, and three years later he received a call to the chair of constitutional and international law at Greifswald, a position which he held until his death. In 1886 with Laband of Strassburg he founded the Archiv für offentliches Recht? and in the following year he made two notable contributions to Holtzendorff's Handbuch des Völkerrechts under the titles Das offene Meer and Staats Untertanen und Fremde. In the same year he undertook the task of bringing up to date Martens' Recueil gênêral des traités. One of his latest works was a study in German constitutional law being a contribution to the Lippe-Detmold succession controversy under the title Die agnatische Thronfolge im Fürstentum Lippe, published in 1903. His last work was a paper entitled Völkerrecht und Vïlkercourtoisie, contributed to the Laband Festschriften recently published and to which reference is made below.

Dr. Gustav Anchütz, professor of constitutional and ecclesiastical law in the University of Heidelberg, has been called to the University of Berlin. Dr. Anschütz is one of the most distinguished of the German publicists. One of his most notable contributions is the article on German Constitutional Law in the Holtzendorff-Kohler Encyclopcedia of Law, 1904. Dr. Anschütz before going to Heidelberg was a professor at Tübingen.

Dr. Fritz Fleiner, professor of public law at Tübingen, has been called to a similar chair at Heidelberg.

Dr. George Adler, professor of political science in the University of Kiel, died June 11, in Berlin, in the fifty-fifth year of his age.

Adolf Frantz, the distinguished professor of ecclesiastical and constitutional law in the University of Kiel, died in July in the fifty-sixth year of his age. Dr. Frantz was the author of Die Literatur des Kirchenrechts and Lehrbuch des Kirchenrechts.

Samuel E. Moffett, a member of the American Political Science Association, an editorial writer and an author of various political and economical works, died suddenly at his home in New York, August 1, in his forty-fifth year. He was a native of California, received the Ph.D. degree at Columbia, and at different times was a member of the editorial 
staffs of various metropolitan newspapers. At the time of his death he was a member of the editoral staff of Collier's Weekly.

Sir William Randal Cremer, founder of the Interparliamentary Union and one of the most active leaders in the peace movement, died on July 22 at the age of seventy. In 1903 he received the Nobel Peace Prize of $\$ 40,000$ which he gave to the International Arbitration League, of which he had long been secretary.

Dr. Burt Estes Howard has been appointed professor of political science in the Leland Stanford University. Mr. Howard graduated from Western Reserve University and did his graduate work at Harvard, Berlin and Heidelberg, from which latter institution he received the Ph.D. degree in 1904. He is the author of a monograph entitled Amerikanische Bürgerrecht and an excellent book on the German Empire published two years ago, and reviewed in the last number of the Review.

Mr. Thomas Reed Powell has been appointed associate in political science at the University of Illinois. Mr. Powell is a graduate of the University of Vermont and of the Harvard Law School. He has also completed his residence requirements for the Ph.D. degree at Columbia. In the absence of Professor Goodnow during the past year Mr. Powel had charge of his courses in administrative law and the law of taxation.

The David A. Wells professorship of political science at Williams College, recently made vacant by the death of Henry Loomis Nelson, will be filled for the time by the president, Mr. H. A. Garfield, who it is understood, will do as much teaching in connection with the position as his administrative duties will permit.

Mosei Jakovievich Ostrogorski, the distinguished Russian scholar and the author of Democracy and the Organization of Political Parties, published in 1902, has been spending the autumn in the United States studying the American electoral system and the method of conducting a presidential campaign.

Prof. Stephen Leacock, of McGill University, after a year's leave of absence, has resumed his academic duties. During the year Professor Leacock under the auspices of the Rhodes trust, made a tour of the British empire for the purpose of stimulating public interest in some of the important questions of imperial concern in the self-governing colonies. 
In Australasia and South Africa, in particular, he delivered many public addresses to university audiences or to gatherings called by the local governing authorities.

Prof. George G. Wilson, of Brown University, and Admiral Charles H. Stockton were the representatives of the United States at the international conference on maritime law which met in London in October. The purpose of the conference was to prepare a body of rules relating to maritime war, the Hague conference having created an international prize court without making any provision as to the law which it should administer. The conference was called by Great Britain and was participated in by delegates from all the great maritime powers. The principal questions considered related mainly to contraband, blockades, the transfer of belligerent merchant ships to neutral flags and the conversion of merchant ships into men-of-war. Professor Wilson will be absent on leave for the next year and his courses will be given in part by Prof. S. C. Mitchell, of Richmond College.

Harold Dexter Hazeltine, a graduate of Brown University, who was recently called to the position of reader in English law in the University of Cambridge, is the author of a monograph entitled Die Geschichte des Englischen Pfandrechts, a scholarly contribution to English legal history. It was prepared as a dissertation for the doctor's degree in law at the University of Berlin under the direction of Prof. Otto Gierke. (Breslau: M. and H. Marcus, 1907, pp. xxviii + 372).

Prof. C. W. A. Veditz, who organized the college of the political sciences in George Washington University and who acted as its dean during the past year, has resigned the deanship and will henceforth give his time exclusively to the work of teaching. Pending the election of a new dean, President C. W. Needham will act as director of the college.

Dr. Karl F. Geiser has been appointed professor of political science in Oberlin College. Dr. Geiser is a graduate of an Iowa College, did his graduate work at Yale where he received his doctor's degree in 1900, was also a student at Berlin, 1905-1906, and for several years has held the chair of political science in the Iowa Normal College.

Dr. John P. Dunning, of the University of Oregon, has been appointed research fellow in political science at the University of Pennsylvania. 
Mr. Dunning did his graduate work at Princeton, Berlin, Oxford, Paris and Heidelberg, receiving his doctor's degree from the latter university in January, 1908.

Three of the ten delegates appointed by Secretary Root to represent the United States at the first Pan-American scientific congress at Santiago, Chili, December 25 next, are professors of political science. They are Dr. L. S. Rowe, of the University of Pennsylvania, who has been elected chairman of the delegation, Prof. Paul S. Reinsch of Wisconsin, and Prof. Bernard Moses of California. Professor Rowe has been in the Argentine Republic since August, studying the political institutions of that country. Three professors of history are also among the delegates appointed. They are Professors Bingham of Yale, Coolidge of Harvard, and Shepherd of Columbia.

The Bulletin of the International Bureau of American Republics, which, under the management of Mr. John Barrett, Director of the Bureau, has grown to be a very attractive and valuable publication, will hereafter be published monthly in two sections, one exclusively in English and the other in Spanish, Portuguese and French. The change is made to avoid the large amount of duplication and unwieldiness which have heretofore characterized the Bulletin. Henceforth, English will be omitted from the foreign edition, and French, Spanish and Portuguese will be omitted from the domestic edition. The subscription price for either edition will be $\$ 2$ per year in all countries of the union and $\$ 2.50$ in all others. The July issue is given up mainly to a carefully prepared annual review of Latin-American trade conditions, and constitutes a useful handbook of North and South American commerce.

Mr. Asher C. Hinds' Parliamentary Precedents of the House of Representatives, a note concerning which was published in a recent number of the Review, is expected to appear in eight volumes from the government printing office before the first of December.

The publication by the government of Francis Newton Thorpe's Charters, Constitutions and Organic Laws, for the purchase of which congress appropriated $\$ 10,000$ at the last session has been postponed and the matter is now in litigation, some question having arisen between the author and the joint committee on library concerning the manuscript. 
Dr. L. Oppenheim, professor of international law in the London School of Economics and Political Science has been appointed to the Whewell chair of international law at Cambridge. Dr. Oppenheim formerly held professorships at Basel and Freiburg, and is the author of a treatise on international law in two volumes, published a year ago.

Prof. Joseph Redlich, of the law faculty of Vienna, has been appointed lecturer on government at Harvard for the second half of the present year. Dr. Redlich has achieved a wide reputation as an authority on English institutions by his treatise in two volumes on English local government, published in 1904, and still more by his elaborate work on the procedure of the house of commons, published two years ago and recently translated into English by A. E. Steinthal. He will give two courses, one dealing with continental, the other with English institutions.

President Benjamin Ide Wheeler, of the University of California, has been chosen by the Columbia faculty of political science as the Roosevelt professor at Berlin for the year 1909-1910, while Dr. Albrecht F. K. Penck, professor of geography and director of the geographical institute of Berlin, has been appointed Kaiser Wilhelm professor at Columbia for the year 1908-1909.

Miss Lucile Eaves, formerly instructor in history at Stanford University, and for the past seven years prominently connected with settlement and other philanthropic organizations in San Francisco, has just been called to the department of political science and sociology in the University of Nebraska as associate professor of practical sociology. The department mentioned was established two years ago; and already it has a class-enrollment of 340 students.

Prof. F. J. Goodnow has resumed his duties at Columbia after a year's absence, during which he made a tour around the world. He spent the winter in studying colonial administration in India and the Straits Settlements. In the spring he visited Australasia and later the Philippine Islands.

Prof. John A. Fairlie, of the University of Michigan, during the past half year has been in the service of the United States bureau of corporations preparing the report on inland waterways, the material for which 
was gathered by the bureau last year. During Professor Fairlie's absence his courses were given by Prof. John B. Phillips, of the University of Colorado.

Dr. M. B. Phillips, of the University of Wisconsin, has accepted a call to the chair of history and political science in Tulane University. Mr. Phillips is a graduate of the University of Georgia, received his doctor's degree at Columbia, and is the author of a study entitled Georgia and States Rights and a monograph on The History of Transportation in the Eastern Cotton Belt.

Mr. Frederic C. Bramhall, who for the past year served as sociology librarian of the New York State Library has resigned to accept an instructorship in political science in the University of Chicago. Mr. Bramhall did both his graduate and undergraduate work in Chicago receiving his $\mathrm{Ph} . \mathrm{D}$. degree from there recently.

The chair of politics at Princeton, made vacant by the resignation of Professor Garfield, has been filled by the appointment of Mr. Henry J. Ford, well known as the author of The Rise and Growth of American Politics. Mr. Ford is an editorial writer by profession and for several years past has been a member of the staff of the Baltimore News, during which time he has held the position of lecturer on political science in Johns Hopkins University.

Although much improved Prof. John Bassett Moore will not resume his academic duties at Columbia until September, 1909. His courses in international law will continue to be given by Dr. George Winfield Scott. Meanwhile Professor Moore's work of editing the writings of James Buchanan is proceeding, the fourth volume having recently appeared.

At the International Exhibition to be held at Brussels in 1910, an international congress of administrative sciences will be convened. The object of the congress is announced to be "to give both students and administrators an opportunity of meeting and of examining in common some of the aspects of the serious problems that have been raised in our days by the growth of our urban populations and by the evolution of the modern idea of the State." The papers and discussion are later to be published in a series of volumes. 
The second educational conference on state and local taxation was held in Toronto, Canada, October 6 to 9 . A volume containing the papers read will shortly be published.

A new charter was adopted by Kansas City, Mo., at a special election held August 4. No distinctive change is made in the framework of government, but many functions are transferred from the council to appointive administrative boards, thus relieving the council of much routine work. Other important features of the charter are the provisions for the referendum, competitive examinations for parts of the municipal civil service, restrictions upon the municipal authorities in the granting of franchises, and enlargement of the power of the city to acquire and operate public utilities. The charter went into effect September 3, though the provisions as to civil service examinations do not become completely operative until 1910.

At the same election an alternative section providing for the "recall" of public officers was voted on separately. This section was approved by about two-thirds of those voting for the charter, but failed of adoption because it did not receive the majority required by the constitution for the ratification of a charter or amendment thereto-namely, four-sevenths of the votes cast in the charter election.

Upon the call of the Commercial Club of Webb City, Mo., a meeting of representatives of Missouri commercial clubs and city councils was held at Kansas City, September 22, for the purpose of considering the formation of a league of Missouri municipalities.

Prof. Bernard Moses, of the University of California, has lately published a book entitled South America on the Eve of Emancipation (New York, Putnam's, 1908), being a political history of the southern Spanish American colonies during the last half century of their dependence upon Spain. In this connection it may be noted that a new edition of $\mathrm{Wm}$. L. Scrugg's Colombian and Venezuelan Republics has been published by Little, Brown and Company. Several of the chapters have been rewritten and a new chapter on the Panama Canal added.

Practical Citizenship, by Rev. Adolph Roeder, is the title of a volume recently published by the Isaac $\mathrm{H}$. Blanchard Company, in which is embodied the result of the author's experience as president of the New Jersey Civic League and an officer in numerous other civic organizations. 
The Ideas of the Republic is the title of a new book by Mr. James Schouler, being a study of the "origin and development of those ideas in civil government which have influenced the growth and progress of the United States as a world power among the nations" (Boston, Little, Brown and Company, 1908). The work is based on a series of lectures delivered at Johns Hopkins University and deals with such topics as the rights of human nature, racial types and equality, government by consent, the discipline of liberty, parties and party spirit, three departments of government, etc.

Prof. J. M. Callahan has published in the West Virginia University Studies in American History an interesting study of Russo-American relations during the civil war.

Hon. W. O. Hart of the New Orleans bar, has published in pamphlet form (Fragments of Louisiana Jurisprudence, Baton Rouge, Daily State Publishing Company, 1908, pp. 150) a series of lectures delivered by him in 1907 to the law class of the Lousiana State University.

The June, 1907, issue of the John P. Branch Historical Papers, published by the department of history of Randolph-Macon College, contains an interesting article by Professor Wm. E. Dodd on John Taylor, Prophet of Secession. In the same issue a number of the letters of Taylor are printed.

Recent volumes in the Columbia University Studies in History, Economics and Public Law are: Ohio before 1850; A Study of the Early Influence of Pennsylvania and Southern Population in Ohio, by Robert E. Chaddock; Consanguineous Marriages in the American Population, by George B. Louis Arner; Factory Legislation in Maine, by E. Stagg Whitin; Adolphe Quetelet as Statistician, by Frank H. Hawkins.

The American Branch of the Association for International Conciliation has recently issued the following leaflets: The Possibilities of Intellectual Coöperation between North and South America, by L. S. Rowe; America and Japan, by George Trumbull Ladd; The Sanction of International Law, by Elihu Root; The United States and France, by Barrett Wendell.

The generosity of a number of societies and individuals in providing a guaranty fund has made possible, for the next five years at least, an 
annual bibliography of all books and articles of value relating to American history. The volume for 1908, compiled by Grace Gardner Griffin, has appeared (Writings on American History, 1906, The Macmillan Company, New York, 1908, pp. 186, price \$2.50). The material is classified under various topical headings, one being politics, government and law, the sub-titles being diplomatic history and foreign relations, Monroe doctrine, constitutional history and discussion, politics, law and national government and administration, State and local government and administration.

A history and description of the organization and operation of the successful Amana Community has been published by the State Historical Society of Iowa. (Amana, The Community of True Inspiration, Iowa City, 1908, pp. 414). The author is Bertha M. H. Shambaugh. The treatment is an adequate one, the tone sympathetic and the English especially graceful. The paper, binding and typographical makeup of the volume conform to the very high standard of excellence set by all the publications of the Iowa Society.

International Documents: A Collection of International Conventions and Declarations of a Law-making Kind, edited with introduction and notes by E. A. Whittuck, has been published by Longmans, Green and Company. The collection contains the French and English texts of the declaration of Paris, 1856, the convention of Geneva, 1864, with the additional articles of 1868, the declaration of St. Petersburg, 1868, the Geneva convention of 1906 , and the final acts and conventions of the Hague peace conferences of 1899 and 1907, together with the list of reservations. In an appendix are given the instructions given to the British plenipotentiaries, by this government, and reservations by Sir Edward Fry on the results of the conference.

The REview welcomes the appearance of a new journal devoted to the political interests of the Philippine Islands. The Encyclopedia Filipina, published monthly in Manila, is under the editorial management of Felipe G. Calderon. The text is Spanish, and the subscription price $\$ 4$ a year. In the May, 1908, issue is reprinted the presidential address of Mr. F. N. Judson, delivered last December before the American Political Science Association.

Another new journal of colonial interest is The American Colonial Review and Intertropical Magazine, the firstissue of which is dated May, 
1908. The journal is edited and published monthly by Louis V. de Abad, Washington and New York, the subscription being $\$ 3$ a year. A Spanish edition is also issued-Revista Colonial Americana y Magazine Intertropical, the contents of which, however, are not exactly the same as of the English edition. The editor in his introductory statement says: "We firmly believe the time has arrived to bring to the public of both Americas in a more extensive manner than heretofore the questions of peculiar interest to these Latin and Anglo-Saxon peoples *** With this object in view, we shall divide our articles into two groups, one embracing all matters of Latin-American international polities, and the other the American colonial policy. This second will comprise all topics touching the territories which are dependent upon the United States or those peculiarly within its sphere of influence."

Prof. Paul Laband of Strassburg has recenty contributed a brief study to the literature of German constitutional law and public finance under the title Direkte Reichssteuern, ein Beitrag zum Staatsrecht des Deutschen Reiches (Berlin: Liebmann, 1908, 70 pp.) in which he opposes direct taxes for the empire and attacks the system of state contributions (Matrikularbeiträge). The essay is marked by the author's usual charm of style and insight. Dr. Laband has recently celebrated the fiftieth anniversary of his doctorate. In commemoration of the event a group of distinguished scholars in his field have united in the preparation and publication of two volumes of Festschriften containing monographs on a variety of subjects in public law and political science (Tübingen: Mohr, 614 and 514 pp.) Among the better known contributors are Van Calker of Giessen, Fleiner of Tübingen, Jellinek of Heidelberg, Otto Mayer of Leipzig, Piloty of Würzburg, Preuss of Berlin, Rosenthal of Jena, Richard Schmidt of Freiburg i. B., Stoerk of Greifswald, Triepel of Tübingen and Zorn of Bonn.

Professor Laband was the recipient of various honors on the occasion of his academic jubilee, among which may be mentioned his elevation to the Prussian privy council, and the Prussian Order of the Red Eagle, etc.

The International Congress for Historical Sciences was held in the hall of the reichstag in Berlin from August 6 to 12, and was attended by nearly 1000 historians from all parts of the world. The proceedings were conducted in seven sections, one of which was devoted to the history of law and economics. Dr. Otto Gierke of Berlin was the leader of the latter section, and Sir Frederick Pollock and Prof. Heinrich Brunner were 
its vice-presidents. Addresses of note before this section were made by Professor Altamira of the University of Oviedo on the actual state of the study of legal history in Spain, by Otto Fischer of Breslau, on the aims and methods of legal history teaching, by Professor Vinogradoff on national law and equity in English jurisprudence of the sixteenth century, and by Sir Frederick Pollock on government by committees in England.

The Story of British Diplomacy by T. H. S. Escott (London: 1908, pp. 420) is a sketch in fifteen chapters of the makers and movements of British diplomacy, mainly in the eighteenth and nineteenth centuries. There are some good sketches of diplomats like Canning and Palmerston, but the attempt to cover so large a field in so small a volume made it necessary to treat too briefly many subjects that deserve more extended consideration.

Recent political tendencies in England have called out a number of books, brochures and pamphlets on socialism, most of which are devoted to combating what is considered a drift toward state socialism by the present government. One of these, entitled Political Socialism in England, is a collection of papers by Lord Balfour of Burleigh, Lord Hugh Cecil, Percy Wyndham and others, and in the main is directed against the old age pension scheme (London, P. S. King). Another, entitled English Socialism of Today, by the Rt. Hon. H. O. Arnold-Forster, M. P (New York: Dutton, 1908, pp. 226), is a popular examination of the demands of the English socialists, and an exposition of their fallacies. He quotes from the socialist programmes to show that they teach the doctrine that class hatred and class war are inevitable and that one of their methods of action is to stir up conflict among the upper and lower classes. Under the caption What is Socialism Mr. Forster distinguishes between the socialism of the philosophers, the socialism of the active propagandists and the socialism of every day life. The latter he contends means nothing more than the actual expropriation of private property. On the whole he affirms that the actual teaching of the socialists are in many respects dangerous and contrary to public policy, and that the time has come when a systematic war should be waged against it.

Vital American Problems, by Harry Earl Montgomery (New York: Putnams, 1908, 384 pp.), is the title of a book which attempts to state the real character of the "trust," "labor" and "negro" problems and 
which offers a solution for each. The trust he asserts is solely the result of the evolution of industrial progress, and is not in any sense an "excrescence on the commercial and industrial body politic." The solution lies in federal incorporation, the assessment of a tax of one-tenth of one per cent upon capital stock, a stricter personal liability of stockholders and directors, more definite reports to the government and greater responsibility, etc. The solution of the labor problem, he asserts, would be facilitated by requiring all corporations employing laborers to employ only by means of a written contract, no contract to be binding unless signed by the parties thereto. The said contract should state clearly the terms of service, the kind of service to be rendered and the wages to be paid, and its strict performance should be compelled by the courts. Where this plan is insufficient the solution may be reached through the more drastic means of compulsory arbitration. Nearly one-half the book is devoted to the negro problem, the solution of which, we are told, must come through education and religious influence.

Prof. Hutton Webster, of the University of Nebraska, is the author of a book entitled Primitive Secret Societies: A Study in Early Politics and Religion (New York: Macmillan, 1908, pp. 227) originally prepared as a dissertation for the doctorate in political science at Harvard. He discusses at length the primitive institution known as the "Men's House," the separation of the sexes, the puberty institution, secret rites, the power of the elders, the development, function and decline of tribal societies, clan ceremonies, etc. The study bears evidence of wide and careful research as well as industry and skill in the arrangement of material.

The subject for the Baldwin prize essay for the year 1908-1909 is A Study of the Practical Operations of Government in Some Large American City. Competitors will be allowed to select any city of the United States having a population of not less than 300,000 . The essays must not exceed 10,000 words in length and must be delivered before March 15 next to Clinton Rogers Woodruff, secretary of the National Municipal League, North American Building, Philadelphia. For additional details concerning the conditions of the competition inquiries may be addressed to Prof. W. B. Munro, Harvard University, Cambridge, Mass. In 1906; the first year in which the prize was offered, twelve essays were submitted, in 1907, nine were submitted and in 1908, eighteen were submitted. 
The joint meetings of the National Municipal League and the American Civic Association will be held this year at Pittsburg, November 17 to 20. One session of the League will be devoted to public utility commissions, one to the conservation of national resources, one to charter and electoral reforms, one to instruction in municipal government and one to "militant citizenship." Bill-boards, the smoke nuisance, the fight against flies and mosquitoes, local improvement and school extension will receive attention at the hands of the Civic Association. There will be two joint sessions, one devoted to municipal sanitation, the other to the Pittsburg survey now being carried on under the auspices of the Sage foundation. The annual address by President Bonaparte of the Municipal League will be delivered Wednesday evening. Hon. George W. Guthrie, Mayor of Pittsburg, for years an active member of the League, is chairman of the committee on arrangements.

A catalogue of the Chicago Municipal Library has been compiled under the direction of Frederick Rex, assistant city statistician, and published by the bureau of statistics and Municipal Library (Chicago, 1908, 149 pp.). Most persons who have occasion to consult this catalogue will be astonished at the extent of material relating to municipal government that has been collected by the bureau of statisties during the short period of its existence, the total number of books, pamphlets, magazines and typewritten folios listed, amounting to 15,000 .

A Bibliography of Municipal Betterment has been published by the Kansas City Public Library. There are respectable lists of books on baths, charities, child labor, cities, citizenship, elections, food and food adulteration, housing problem, and so on through the alphabet. There is also a 47 page list of periodical articles, under appropriate headings.

The 1907 volume of the Proceedings of the National Conference for Good City Government and the Thirteenth Annual Meeting of the National Municipal League fully measures up to the high standard set by the editor, Clinton Rogers Woodruff, in the previous volumes. The Providence meeting was in many respects the most notable meeting the League has held. There were in all seventeen sessions and eighty-one speakers. The present volume contains all the papers prepared for the meeting of the League and a number presented at the joint session with the American Civic Association, on municipal health and sanitation. Worthy of note are the four papers on the commission form of municipal govern- 
ment, easily the best of which is that by Prof. W. B. Munro of Harvard University, on the Galveston plan.

A valuable study of the cost of municipal government in Massachusetts has been made by the bureau of labor statistics of that State, the results of which are published in a volume of 300 pages, being the first annual report on the comparative financial statistics of cities and towns. The investigation was undertaken in pursuance of an act of the general court passed in 1906, which requires the accounting officer in each city and town in the commonwealth to furnish annually to the bureau of labor and statistics a summarized statement of all revenues and expenditures for the preceding fiscal year. The report shows the amount expended for the various municipal services in each city from which some interesting comparisons are made. The investigation reveals some conditions which should receive the attention of the legislature, such, for example, as the lack of system in handling receipts and making disbursements, defects in methods of accounting, the administration of trust funds, etc. Altogether, the report is a creditable piece of investigation, and throws much light on some of the important questions of municipal finance.

New bibliographical lists published by the library of congress relate to political parties in the United States (28 pp.), the eight hour working day and the limitation of working days in general ( $24 \mathrm{pp}$.), the postals savings bank (23 pp.), and control of commerce.

New publications in the Johns Hopkins series are British Committees, Commissions, and Councils of Trade and Plantations 1622-1675, by Charles M. Andrews; Neutral Rights and Obligations in the Anglo-Boer War, by Robert Granville Campbell; The Elizabethan Parish in its Ecclesiastical and Financial Aspects, by Sedley L. Ware; A Study of the Topography and Municipal History of Praeneste, by R. V. D. Magoffin.

It is announced that Dodd, Mead and Company are to resume publication of their International Year Book, which suspended in 1902 . As Appleton's Annual Cyclopodia was suspended about the same time, we have had no Annuaire comparable to the English Annual Register or the German Geschichte Kalender. Both year books were carefully prepared, and the resumption of one of them will be welcomed by students generally. 
The Annotated Constitution of Michigan in two volumes (published by the Michigan State Library) is a useful reference work jprepared for the use of the late constitutional convention of that State. Each article of the constitution is considered in turn and is then annotated in the usual way in a preliminary pamphlet. Then it is published in separate form with similar provisions in other State constitutions. Thus the topic municipal corporations is treated in a pamphlet of 120 pages, all the constitutional provisions of the several States relating to counties, townships, cities and villages being arranged in order.

Prof. A. B. Hart's Manual of American History, Diplomacy and Government (published by Harvard University, Cambridge, Mass., 1908, pp. 554) is an admirable and useful bibliographical contribution to the literature of American history and government, and should be invaluable to teachers of these subjects. It is, we are told, the rseult of his twentyfive years' experience as a teacher and is based on several previous publications, notably his outlines, suggestions for students, revised suggestions and handbook, all of which have proved helpful to teachers. The material for each, however, has been entirely worked over and rearranged, so that the present volume is substantially a new work. It is divided into five parts devoted successively to method and materials, lectures and readings, class-room papers, library reports and examinations. It provides an outline and guide for six different courses; four on the development of American diplomatic and political history, two on American government. There is also a list of more than 100 topics for class-room reports and more than 1000 subjects for library reports.

Two noteworthy bulletins of the University of Wisconsin recently published (Economics and Political Science Series) are The Labor Contract from Individual to Collective Bargaining, by Miss Margaret Schaffner, and The Labor History of the Cripple Creek District, by Benjamin M. Rastall.

Mr. Clifford S. Walton, of the District of Columbia bar, is the compiler and editor of a commercial and maritime code of Latin-America in five volumes. The work is published in Spanish under the title Leyes Commerciales y Maritimas de la América Latina, by the department of state of the United States for the use of diplomatic and consular officers (Washington: Government Printing office, 1907). The work is a careful compilation from official sources and should prove useful to students of maritime law. 
Another contribution has been made to the literature dealing with the international law and diplomacy of the Russo-Japanese war. The author of this latest work is Sakuye Takahashi, professor of international law in the imperial university of Tokyo and vice-president of the International Law Association of London. The work is entitled International Law Applied to the Russo-Japanese War with the Decisions of the Japanese Prize Courts (xviii, pp. 805, London: Stevens and Sons, 1908). Mr. Takahashi during the war was a member of a council appointed by the Japanese government to assist in the direction of the war and gave his advice on a number of questions of international law which arose during the conflict. He had also served as a legal adviser to the commander of the fleet during the war with China, and later prepared a volume of Cases on International Law during the Chino-Japanese War.

The present work is divided into five parts dealing successively with the commencement of hostilities, the laws and customs of war on land, the laws of maritime war, neutrality and prize cases decided by the Japanese prize courts, of which there were two inferior and one superior tribunal established. The author shows conclusively, as Hershey and Smith and Sibley had already shown in their treatises, that Japan was guilty of no violation of international usage in beginning hostilities without a preliminary declaration, and he contends that Japan in all other respects, notably in the treatment of prisoners, constantly observed the well established rules of war. The Russian charge that Japanese troops were guilty of firing on Red Cross trains he flatly denies. All the various questions raised, notably those relating to contraband, trade with the enemy, rights of refugee vessels in neutral ports, etc., are discussed intelligently and, on the whole, impartially. In part five the decisions of the Japanese prize courts are reproduced and explained. There is an appendix containing the texts of various important documents, such as the instructions for the government of the forces, prize regulations, the treaty of peace, etc.

An interesting contribution to the literature of international law and diplomacy has been made by a Belgian advocate, Gaston de Laval, under the title De la protection diplomatique des nationaux à l'étranger. The author calls attention to the increasing rôle which diplomatic intervention in the interest of nationals has come to play in the relation of states, as a result of intercourse and residence. He discusses the rights of nationals in foreign countries, the conditions under which they are entitled to the protection of the governments to which their allegiance 
is due, examines the objections which are often raised to the principle of diplomatic intervention for the protection of individuals, and reviews in detail the cases of intervention arising from expulsion, impressment into military service, etc. M. de Laval's treatise contains much information that will be useful to diplomatic agents upon whom calls are so often made for the employment of their good offices or authority for protection against the action of the local authorities (Brussels: Bruylant, 1907,188 pp.).

Coleman Phillipson, an English barrister, has published a study entitled Two Studies in International Law (London: Stevens and Haynes, 1908 , pp. xviii +136 ), one dealing with the influence of international arbitration on the development of international law; the second, with the rights of neutrals and belligerents in regard to submarine cables, wireless telegraphy and the interception of messages in time of war. In the first essay the author reviews in detail the various arbitration projects from ancient times to the present day, discusses the modern conception of arbitral procedure and reviews the principal cases in which arbitration was resorted to in the nineteenth century. The second essay dealing with the rights of neutrals and of belligerents with regard to telegraphic communication in time of war is a clear, concise and accurate discussion, both from the historical and legal point of view.

Il rapporto di neutralita by Guiseppe Ottolenghi (Turin: Unione tipografico-editrice terinese, 1907, pp. 518) is an excellent study of the legal nature of neutrality. The author rejects the view of most writers that neutrality is a condition of fact. He examines the different theories concerning the basis of the neutral relation, none of which, he maintains, affords a satisfactory solution of the question. Then follows a discussion of his own theory based on the fact that neutrality is a voluntary act and that the will of states is an essential coefficient in its determination. Finally the author discusses in detail the fundamental duties of belligerent states toward neutrals, the obligations of neutrals, the legal status of neutral subjects, contraband of war, etc.

Guerre maritime et Neutralite is the title of an official publication of the Russian government containing a collection of treaty provisions and legislative acts of various countries relating to the rules of maritime warfare and the rights and duties of neutrals. It was intended to serve as a rough code of maritime law for the use of the second Hague conference. 
The work is divided into three parts: the first, containing the texts of various acts, such as the declaration of Paris of 1856; the second, the conventional agreements of different states; and third, legislative provisions and executive orders. The collection was prepared by André Mandelstam, dragoman of the Russian embassy at Constantinople and Baron Noldé of the Russian foreign office and professor of international law at St. Petersburg (St. Petersburg: Kirschbaum, 1907, pp. 341).

An Italian writer, Arrigo Cavaglieri, professor in the Institute of Social Sciences at Florence, is the author of a little book entitled L'elemento consuetudinario nel diritto internazionale privato (Padua: Drucker, 1908, 130 pp.) being a study of the element of custom in private international law. He attempts to show that in private international law as in public international law custom plays a great rôle and that it is the source of many of the rules which govern where there is a conflict of legal systems. This study is in a way a complement to the author's work on the Element of Custom in Public International Law, published a year or two ago.

Louis Pérez Verdia, a deputy in the Mexican congress and professor of international law in the School of Jurisprudence of Guadalajara, has published an elementary treatise on private international law under the title Tratado elemental de derecho internacional privado (Guadalajara, 1908, pp. 359). The first three chapters deal with definitions, principles and theories. The author then takes up the subjects of personality, domicile, capacity, absence, marriage, separation, divorce, paternity, guardianship, etc. The later chapters deal with questions of procedure, competence, execution of judgments, extradition and effect of sentences.

A flood of books and brochures dealing with the work of the second Hague peace conference is now offered to the public. Perhaps the most important of these contributions is La Seconde Conférence de la Paix, by Ernest Lémenon, an advocate before the court of appeal at Paris (Paris; Pichon et Durand-Auzias, 1908, pp. 800). The introductory chapters give a résumé of the work of the first peace conference at the Hague, the origin of the second conference including the negotiations leading up to it and a review of the preliminaries of the second conference. Then follow a series of chapters dealing in succession and in detail with the work of each of the commissions, a "title" being devoted to each commission. The work is an analysis not only of the several 
acts of the conference, but of the numerous deliberations; the various propositions, counter-propositions and amendments relative to each subject considered-a feature which is necessary to the proper appreciation of the work of the conference. There is a final chapter in which the author sums up his conclusions and gives an appreciation of the work of the conference as a whole. The distinguished senator of the French republic, Léon Bourgeois, who was at the head of the French delegation to the second conference contributes a preface. The work of M. Lémonon is marked by good judgment, is free from partiality and is in every way a valuable study.

A German work far less comprehensive is Die Zweite Haager Konferenz: Ihre Arbeiten, ihre Ergebnisse und ihre Bedeutung, by H. Fried (Elischer: Leipzig, 1908, pp. 218). The author divides his work into three parts, the first of which deals with the history of the conference, the second with its work, and the third, with an estimate of its results. $\mathrm{He}$ maintains that the conference was greatly handicapped by the fiction of the equality of the states, which gave Montenegro the same power in determining the work of the conference as was enjoyed by the United States and other great powers. He is particularly severe in his denunciation of the "fetish" of equality, and also attacks the rule of unanimity which prevailed in the deliberations of the conference. He places on Germany in general and on its first delegate, Baron Marschall, in particular, the responsibility for defeating the project for obligatory arbitration.

L'œuvre de la deuxième conférence de la paix: Exposé juridique et texte des conventions by Antoine Ernst (Paris: and Brussels, 1908, pp. 175 ) is an instructive commentary on the several conventions adopted by the conference. The author was the secretary of one of the Belgian delegates.

La Belgique et l'arbitrage obligatoire à la deuxième conférence de la paix (Brussels: Dewitt, 1908, pp. 44) is an anonymous brochure devoted to a justification of the action of the Belgian delegates and other powers who voted against the Anglo-American project for obligatory arbitration. The author supports without reserve the objections which Baron Marschall urged against obligatory arbitration and contends that Belgium favors the principle as far as it concerns controversies which do not affect vital interests, independence or the honor of states. 
An English work, entitled International Problems and the Hague Conference, by Prof. T. J. Lawrence, is announced, and an American work by Prof. James B. Scott is expected to appear from the Johns Hopkins Press at an early date.

Two monographs of interest to students of international law are Exterritoriality: the Law Relative to Consular Jurisdiction and to Residence in Oriental Countries; by Sir Francis Piggott (London: Butterworth, 1908, pp. 326) and The Congo State, Its Origin, Rights and Duties, by A. Castelein (London: Nutt, 1908, pp. 274).

Arbitration in Latin America, by Gonzalo de Queseda, Cuban minister to the United States and delegate to the second peace conference at the Hague, is the title of a little book which reviews the history of the policy of the Latin-American states with regard to the arbitration of international disputes. The author shows that from the independence of these states to the third Pan-American conference at Rio Janeiro in 1906, arbitration has played a great rôle in South American policy. He reviews in succession the acts and declarations of the various congresses and conferences so far as they relate to arbitration, and in a final chapter gives a history of the arbitration movement, citing constitutional and treaty provisions relating to arbitration and the cases which have arisen from time to time and the manner of their settlement (Rotterdam: Wijt and Zonen, 1907, pp. 136).

Henrique Lisboa, a Brazilian diplomat, has lately published a book entitled Les fonctions diplomatiques en temps de paix (Santiago, 1908, pp. 275) in which he dwells upon the increasing rôle which diplomacy plays in modern life on account of the new means of communication, the development of commerce, industry, navigation, science and art, all of which have created new subjects for diplomacy. He shows how the permanent embassy has become a necessity, and insists that diplomacy should be made a professional career. The author offers his work to beginners as a guide and to diplomats in general as a manual to be consulted for rules of diplomatic usage.

Das Staatsbürgerrecht im internationalen Verkehr, by Prof. J. Sieber (Bern: Stämpfli et Cie, 1907), is another contribution in two volumes to the already large and increasing literature of citizenship and international law. The first volume of the present work is a systematic study of the law relating to the many questions that are constantly being raised in 
international intercourse. The doctrines of the jus sanguinis and the jus soli, including the theory of perpetual allegiance, are considered at length. The second volume contains, mostly in translated form, the law of the various countries relating to citizenship. In this connection mention may be made of Baumhägger's Die rechtliche Natur der Naturalization nach deutschen Reichsstaatsrecht (Bonn: Georgi, 1906), a study of the acquisition of citizenship by naturalization according to German imperial law, and the legal nature of the act.

Das Staatshaupt in den Republiken, by Carl Walther (Breslau: Marcus, 1907), is the first systematic study of the executive of republican states. The author describes the various forms of the presidency prevailing in republics and examines the nature of the office as compared with hereditary executives.

Dr. Heinrich Geffcken is the author of a brochure entitled Das Gesammtinteresse als Grundlage des Staats- und Völkerrechts (pp. 61, Leipzig: A. Deichert, 1908) in which he attempts to account for the establishment of social relations between men on the theory that they prefer the general interest to their interest as individuals. He considers the state as an original juridical person which cannot be created by a superior or external will, and whose end is to safeguard the interests of the persons who compose it. He discusses the sovereignty of the state, which he says is a sovereignty of law - a law which is born with the state and the realization of which is the highest end of the state. He dwells particularly on two aspects of the state, namely, its exclusive right over all persons in its territory, and its absolute equality with other states in all international relations. Finally, he examines the various forms of states, sovereign states, federal states, confederations, etc.

Le Condominium franco-anglais des Nouvelles-Hebrides, by N. Politis (Paris: Pedone, 1908, pp. 151), is a study of the origin and history of the Anglo-French administration of the New Hebrides Islands. The author considers in turn the declaration of 1878 and the convention of the same year, the "accord" of 1904 and the convention of 1906. The constitutional status of the territory, the legal condition of the inhabitants and the governmental organization are among the subjects discussed.

International Arbitration as a Substitute for War Between Nations, by Russell Lerois Jones (London: Simpkin, 1908, pp. 269), is a historical monograph on arbitration which received a Carnegie prize in 1907. 
Paul Fauchille, director of the Revue generale de droit international publique, and Nicolas Politis, professor of international law at Poitiers, are the joint authors of a little book entitled Manuel de la Croix-Rouge, à l'usage des militaires de terre et de mer et des sociétés de secours aux blessés, being mainly an exposition of the Red Cross conventions of 1899, 1900 and 1907 and a commentary on the law applicable to war on land and on the sea. There is a preface by Professor Rénault and an appendix containing the texts of the Red Cross conventions (Paris: 1908, pp. 195).

Gaston Jéze, professor of administrative law at the University of Lille, who has recently published a French translation of Goodnow's Principles of Administrative Law, has now translated into French Dicey's Law and Public Opinion in England in the Nineteenth Century. Giard et Brière are the publishers.

La loi: Essai sur la théorie de l'autorité dans la democratie, by Maxime Leroy, is the title of $a$ new contribution to theoretical jurisprudence (Paris: Giard et Brière,1908, pp. 353), in which the author discusses at length such topics as the history of the conception of law, the "order" of law, the "organization" of law, the distinction between law and règlement, judicial interpretation, social solidarity as a principle of law, the doctrinal theory of law, the reign of law in a democracy, etc.

L'Administration de la France: les fonctionaires de gouvernement: le ministère de la justice (Paris: Perrin, 1908, pp. 435) is the title of an excellent work on French administration by Henri Chardon. The author has been a member of the council of state for more than twenty years and possesses a rare degree of familiarity with the details of the French administrative service. His work is an exposition of the governmental organization of France and of its administrative activities as they actually are. The ordinance powers of the prefects, the mayors and the prefectural councils are discussed in detail. The most valuable part of the book is that which deals with the work of the council of state, for it is with this branch of the administrative service that the author is most familiar. Two years ago he published a volume dealing with the public works of France.

La vie politique dans les deux mondes (1906-1907) is the title of a new annuaire or year book established in Paris and published under the editorship of A. Viallate, director of the Annales des Sciences Politiques, assisted by a number of professorial colleagues in the Ecole des Sciences 
Politiques. It contains a review of political events occurring in the entire world topically arranged. It differs from the French Annuaire, the German Geschichte Kalender and the English Annual Register in that its scope includes all civilized countries. This first number contains 600 pages, of which 50 pages are devoted to France, 60 to the British Empire, 50 to Germany, 50 to the United States and 40 to the Orient. In addition to the chroniques of particular countries there are three chapters on international politics, international acts and economic life. There is also a preface by Anatole Leroy-Beaulieu, an article on the second Hague conference by Professor Renault and an excellent alphabetical index. The publisher is Félix Alcan of Paris.

Appunti di diritto Costituzionale, by Gaetano Mosca (Milan, 1908, pp. 156), is the title of a little treatise on the Italian constitution. After a brief review of the genesis of modern constitutions the author takes up the statuto granted by Charles Albert in 1848 to his Sardinian subjects and accepted by the other Italian states from 1859 to 1870 . Then follow discussions of the king, the cabinet, the parliament, the judiciary, individual rights and the relations of church and state.

Le compromis de 1868 entre la Hongrie et la Croatie et celui de 1867 entre l'Autriche et la Hongrie, by G. Horn (Paris: Libraire générale de droit et de jurisprudence, 1907, pp. 256) is a critical and historical study of the constitutional relations between Hungary and Croatia and between Austria and Hungary, by a Paris advocate, editor and doctor of law. In the first part of his work M. Horn reviews the history leading up to the compromise of 1868 between Hungary and Croatia and attempts to show by analysis the fact that Croatia is a free country with a political and legal individuality of its own, having never been conquered by Hungary, Austria or Germany. It is in fact a plea for Croatian independence. In part two he gives a translation of the compromise pact of 1868 with a commentary on each article. He reproduces also the text of the AustroHungarian compromise of 1867 under each article of the HungarianCroatian agreement which refers to it.

J. C. Bluntschli und seine Bedeutung für die Moderne Rechtswissenschaft is the subject of a memorial address recently delivered at Zürich by Prof. F. R. Meili in commemoration of the one-hundredth anniversary of the birth of Bluntschli. (The address is published by Fussli, Zürich, 1908, pp. 39). 
Prof. Otto Mayer of Leipzig is the author of a study entitled Die juristische Personen und ihre Verwertbarkeit im öffentlichen Recht (Tübingen: Mohr, 1908, pp. 94) being his contribution to the Laband "Festgabe" series. It is a clear and admirable exposition of the doctrine of the juristic personality and may be compared with the excellent French work by Michoud published two years ago under the title Théorie de la personalité morale, a work which Mayer does not seen to have consulted.

Dr. Félix Salomon, professor of history in the University of Leipzig, recently the author of a notable biography of Wilhelm Pitt der Jüngere, has lately prepared under the title Die deutschen Parteiprogramme a systematic collection of German party programmes or platforms from the beginning of the constitutional era in Prussia to the year 1900. The collection is divided into two parts; part one contains the programmes from 1844 to 1871 ; part two, those from 1871 to 1900 (Leipzig: Teubner, 1907). A somewhat similar work, though more than a compilation, is Chr. Grotewold's Die Parteien des deutschen Reichstages (Leipzig: Wigand, 1908 , pp. 339), being a review of the programmes and tendencies of the various parties in the reichstag.

A new edition (the fifth since 1900) of Professor Berthélemy's Traité élementaire de droit administratif has been published (Paris: Rousseau, 1908, pp. $\mathrm{xi}+982)$. The new edition possesses valuable bibliographical notes and numerous references.

Römisches Recht und Pandakten-Recht in Forschung und Unterricht (Berlin: Vahlen, 1907, pp. 80) is the title of a brochure by Prof. Fritz Litten of Halle, in which he attempts to describe the place, which, in his opinion, Roman law should occupy in science and in legal instruction, particularly in Germany where the study of the new civil code threatens to displace Roman law in the universities. Professor Litten with Leonhard of Breslau and a few others see cause for alarm and pleads for the retention of Roman law in the German system of legal education. Still another contribution to the discussion has been made by Prof. Leopold Wenger under the title Die Stellung des offentlichen rimischen Rechts im Universitäts Unterricht (Wien: Manz, 1907, pp. 40).

A new and enlarged edition of 'Windscheid's Lehrbuch des Pandektenrechts in three volumes has been prepared by Theodor Kipp, professor in the University of Berlin (Frankfort: Rutten und Leoning). The 
new edition is augmented by 250 pages of new matter, and is enriched by an excellent bibliography covering the legal literature of recent years.

A new edition (the second) of Brunner's Deutsche Rechtsgeschichte has recently appeared from the press of Duncker and Humblot. The new edition contains 200 pages of new matter, an elaborate index of 40 pages and a bibliography brought down to date.

The second volume of the new Zeitschrift für Völkerrecht und Bundesstaatrecht founded two years ago by Dr. Josef Kohler has appeared. It contains the usual number of signed articles, reviews, documentary texts and chroniks. Among the more important articles may be mentioned The International Status of a Tunnel under the English Channel, by Professor Oppenheim of London; Critical Jurisprudence and Juristic Persons, by Walter Pollock of Berlin; International Law as a Title of Private Law, by Dr. Josef Kohler; Contraband of War in Theory and Practice, by Dr. Paul Posener of Berlin; Studies in the History of International Law in the Far East, by Herbert Mueller of Berlin; Modern Non-political International Unions and Congresses and International Law, by William Kaufmann; and The Proper Field of International Law in Theory and Practice, by Prof. Otfried Nippold.

The Trade and Administration of the Chinese Empire, by Hosea Ballon Morse, a graduate of Harvard, member of the Royal Asiatic Society and commissioner of customs in China (New York: Longmans, 1908, pp. 451 ) is a concise, clean cut and reliable description of the economic and political state of the Chinese empire, based on the author's observations and experiences of thirty years residence in China. The government, the financial system, extraterritoriality, foreign commerce, internal trade, the opium traffic, the customs service and the postal system are all discussed in detail and in an interesting manner. The chapters on the imperial customs and postal system, built up by the administrative genius of Sir Robert Hart are entitled to special mention.

Mr. Frederick Stimson, whose Lowell lectures, published under the title The American Constitution were reviewed in the last number of the REviEw, has lately published a more comprehensive work entitled The Law of the Federal and State Constitutions of the United States (Boston: The Boston Book Company, 1908, pp. xxii +386 ) originally prepared for use in his classes at Harvard University. It is divided into three books, the first 
of which deals with the origin and growth of the American Constitution, the second with the principles of civil liberty as expressed in English statutes and American constitutions, while the third is in the main an analysis of the State constitutions. The second and third books are merely compilations, only the first being in the nature of a commentary. Mr. Stimson laments that historians and writers on constitutional law have over-emphasized the political provisions of the Constitution-the frame of government-to the neglect of that which is most important, namely the liberties of the people. He therefore turns his attention more directly to the "broader principles of individual rights" to which he devotes some ten chapters dealing with fundamental rights, such as the "right to law" (i.e., the right of the individual to resort to the courts in case of any dispute with a private person or with the government), the right of personal liberty, the right to labor and trade, the right to property and various other "cardinal rights of less importance" including the right to take part in the government. In a chapter on chancery and the injunction order he discusses the history of the use of the injunction with particular reference to its employment in labor disputes, and concludes that its use in such cases is objectionable, not only for the historical reason that it is in derogation of the common law, but also "because it tends to make the courts no longer judicial, but in effect part of the executive branch of the government." In his chapter on the right to labor and to trade he renews the claim, discussed more at length in his volume on The American Constitution, that the bulk of our antitrust legislation, particularly that of the States, is unnecessary since the common law remedies are fully adequate. He also renews his attack upon the recent federal railway legislation, but happily refrains from the rather intemperate criticism which characterizes his previous work. In his discussion of governmental organization he eulogizes the principle of the separation of powers as the "most important of all our governmental principles, analyzes the arguments for and against the initiative and referendum, and criticises the increasing verboseness of our newer constitutions. Book II contains an elaborate classification of English and American constitutional principles under such heads as jury trial, habeas corpus, elections, freedom of speech, etc; also a historical digest of important English social legislation, from the conquest to the present time. The most useful part of Mr. Stimson's work is undoubtedly Book III, which takes up more than one-half of the entire volume. It is an elaborate comparative digest of the State constitutions in 996 sections. The digest seems to be carefully and thoroughly done and the arrange- 
ment is logical and scientific. As a whole the work adds nothing to the reputation which Mr. Stimson's American Statute Law gave him. It is not a scientific treatise or commentary which will take an important place in the literature of constitutional law, but it will prove useful to students and teachers.

Professors Moreau and Delpech, of the University of Aix-Marseille, have rendered a valuable service to students of comparative government by their recently published two volume work entitled Les Réglements des Assemblées legislatives. An exhaustive compilation has been made of the rules governing the action of each of the houses of legislature of the following countries; Germany, Prussia, England, Austria-Hungary, Belgium, Spain, the United States, Greece, Italy, Norway, Holland, Sweden and Switzerland, including also the cantons of that country. Such constitutional or statutory laws of the various states as affect the legislative bodies of the respective states are given before the rules of the legislative bodies themselves. In addition to excellent tables of contents in each book, there appears at the end of the second volume a very complete general alphabetical index of 75 pages, which renders the work particularly serviceable. (Les Régléments des Assemblées legislatives. By Felix Moreau and Joseph Delpech. Paris: V. Giard et E. Brière. Price, 30 francs.) 